\title{
CrimRxiv
}

\section{Problematizing the Rule of Law Agenda in the SDG Context}

Danielle Watson ${ }^{1}$, Ariel Yap ${ }^{2}$, Nathan W. Pino ${ }^{3}$, Jarrett Blaustein ${ }^{2}$ ${ }^{1}$ Queensland University of Technology, ${ }^{2}$ Monash University, ${ }^{3}$ Texas State University

Published on: Dec 08, 2020

DOI: 10.21428/cb6ab371.ba393049

License: Creative Commons Attribution 4.0 International License (CC-BY 4.0). 
Author Accepted Manuscript. Please quote the final published version: https://doi.org/10.1108/978-1$\underline{78769-355-520201010}$

\begin{abstract}
Despite a global consensus that rule of law is desirable, there are important debates about what this entails and how it can be achieved or supported in developing and transitional countries of the Global South. Accordingly, this chapter considers the importance and contextual suitability of rule of law as a building block for 'peaceful and inclusive societies' in the context of the Sustainable Development Goals (SDG). We begin by examining key definitional debates and consider the challenges inherent to monitoring progress towards SDG target 16.3 which seeks to 'promote the rule of law at the national and international levels, and ensure equal access to justice for all'. We proceed to illustrate some of these definitional and methodological limitations by considering how favourable rankings of model Western democracies mask rule of law deficits that relate to access to justice and the protection of human rights for marginalised populations. This critique highlights an important point that is repeatedly emphasized throughout the rule of law literature: rule of law is not an end state but rather, an ideal that all countries must continuously work to realise and sustain. The remainder of the chapter considers the challenges of promoting a Western rule of law agenda in a failed and titular democracy (the Solomon Islands) and a peaceful and prosperous country (Singapore) which adheres to a 'thin' definition of the rule of law that does not conform with liberal ideals.
\end{abstract}

\title{
Key words
}

Rule of law, culture of lawfulness, crime-development nexus, Sustainable Development Goals

\section{Introduction}

Since the 1990s, the rule of law has occupied increasing amounts of discursive space across legal, economic development, human rights, democratisation, political and state-building sectors (Krygier 2011; Selous 2016). Today, 'rule of law' sits at the heart of Sustainable Development Goal (SDG) 16 which calls upon Member States to 'Promote peaceful and inclusive societies for sustainable development, provide access to justice for all and build effective, accountable and inclusive institutions at all levels' (A/RES/70/1, 2015; see also A/RES/67/1). SDG target 16.3 specifically seeks to 'promote the rule of law at the national and international levels, and ensure equal access to justice for all.' The inclusion of SDG 16.3 reflects the culmination of a historical process described by Carothers (1998) whereby rule of law emerged as a mainstay of international development discourse in the wake of the Cold War. Nearly three-decades later, there remain important debates about how the rule of law should be promoted or supported in developing and transitional countries of the Global South (O'Connor 2015). 
A veritable industry has developed in response to a consensus amongst the members of the international community that economic liberalization and democratization provide a recipe for promoting the rule of law at the national and international level (Carothers 2003; Krygier, 2011). This agenda is part of an overarching project of advancing global liberal governance after the Cold War. However, it has also been influenced by concerns about the 'dark side of globalization (i.e. transnational organized crime and corruption; see Blaustein, Chodor and Pino 2020), the rise of the human development paradigm, and heightened international interest in promoting human rights (Carfield, 2005). It is in relation to the latter emphasis on human rights that the aim of improving 'access to justice' for vulnerable populations such as 'women, youth, persons with disabilities, marginalized groups, and displaced communities' around the world (UNDP, 2017: 42)' emerged as an important element of the rule of law agenda, at least within international policy discourse. It is therefore widely accepted by reformers that '[j] ustice is intricately linked to the protection of civil and political rights' (UNDP, 2017: 43) and that the protection of these rights via institutional reforms targeting courts and other criminal justice institutions is crucial for legitimising any legal system and for improving the population's compliance with the law (Carothers, 2003). This conceptualisation of rule of law is appealing from a liberal standpoint $\underline{1}$, but it is not universally celebrated.

As Carothers (2003) and others note, no consensus exists at the international level about what the rule of law is or how it should be defined. This definitional ambiguity, discussed in the following section, renders the prospect of systematically measuring a country's adherence to the rule of law inherently problematic and political. The political nature of the rule of law agenda is readily apparent from the fact that associated aid budgets, interventions, and institutional capacity building projects focus almost exclusively the developing South and non-Western societies. This dynamic in-turn reflects problematic assumption that developed, model democracies of the Global North either already conform to this ideal or are capable of addressing their deficits without the same degree of international oversight or assistance as their non-Western counterparts.

This chapter proceeds to critically reflect on the importance and contextual suitability of rule of law as a building block for 'peaceful and inclusive societies' in the SDG context. In what follows, we begin by examining key definitional debates and a closely related concept, 'culture of lawfulness', which sits at the heart of international efforts to promote the rule of law through education-focused initiatives. We then proceed to consider some challenges inherent to monitoring progress towards SDG 16.3 that arise in relation to the definitional debates and political sensitivities surrounding the concept. We note that these issues are compounded by the methodological limitations of the official indicators and the problems associated with perceptions-based measures including the World Justice Project's Rule of Law Index (World Justice Project 2019). We illustrate some of these limitations by considering the degree to which the favourable rankings of model Western democracies that back the rule of law agenda mask rule of law deficits, particularly in relation to access to justice and the protection of 
human rights for marginalised populations. This critique highlights an important point that is repeatedly emphasized throughout the rule of law literature: rule of law is not an end state but rather, an ideal that all countries must continuously work to realise and sustain. Where culturally and contextually appropriate, we argue that rule of law programming should be grounded in a thick definition that emphasises the protection of civil, political and human rights. At the same time, we acknowledge that extending these ideals to countries which are not model liberal democracies is inherently problematic.

The remainder of the chapter considers the challenges of promoting a Western rule of law agenda in these contexts using two case studies. The first case study highlights the limitations of international efforts to promote the rule of law agenda in a failed and titular democracies by reflecting on the legacy of international state building efforts in the Solomon Islands. This example highlights a fundamental paradox of the rule of law agenda, which is that rule of law programming is typically hardest to institutionalise where, at least from a liberal standpoint, it is needed most. The second case study of Singapore highlights how from a sustainable development standpoint, adherence to a 'thin' definition of the rule of law may be sufficient for promoting peaceful and prosperous societies. This perspective is perhaps unsettling for some readers because the example highlights that order and stability may be created and maintained in the absence of, and indeed at the expense of, fundamental human rights and political freedoms. The case study further illustrates that the international community is willing to tolerate illiberal institutions and practices of government in stable and orderly countries that actively participate in the global liberal economy.

\section{What is the rule of law?}

The concept of the rule of law has been traced back to various pre-modern civilisations including Arab, Greek, Chinese, Indian and Roman (Selous 2016; see also Tamanaha 2004 for Greek and Roman thoughts; Lin Li 2018 for China). One of the earliest examples of this idea can be seen in the Code of Hammurabi $(1760 \mathrm{BC})$ that contained fundamental legal rules that bound society, economic activity and governance (Selous 2016). More commonly however, the idea is associated with the philosophical writings of the rule of law indicate that Aristotle's notions are most frequently cited in English language scholarship (Zanghellini 2016), where themes of 'the rule of law, not man'; 'a government of laws, not men'; 'law is reason, man is passion'; 'law is objective, man is subjective', continue to be discussed (Tamanaha 2012: 243). It is said to be the first "coherent description" (Rodriguez, McCubbins \& Weingast 2010: 1464), even though some suggest that modern rule of law ideas used in the West took root long after classical Greece (Tamanaha 2004; Zanghellini 2016). For example, some scholars associate the concept as it exists today to the Magna Carta of 1215 that sought to restrict the powers of the King of England (Holt 1992). Today, virtually every country claims to adhere to rule of law and the consequential right to rule through associated moral codes and 'legitimising' norms (Sellers 2014; 
Tamanaha 2012). At the same time, rule of law remains a contested and controversial concept (Waldron 2002) as definitional debates centre on 'thin' and 'thick' conceptualisations and the related distinction between 'rule of law' and 'rule by law'.

For its part, the United Nations (2004: 4) defines rule of law as:

a principle of governance in which all persons, institutions and entities, public and private, including the State itself, are accountable to laws that are publicly promulgated, equally enforced and independently adjudicated, and which are consistent with international human rights norms and standards. It requires, as well, measures to ensure adherence to the principles of supremacy of law, equality before the law, accountability to the law, fairness in the application of the law, separation of powers, participation in decision-making, legal certainty, avoidance of arbitrariness and procedural and legal transparency.

This is consistent with 'thick' definitions of the rule of law, which are more or less inextricable from wider, liberal, moralistic and normative concepts of democracy, fairness, liberty, justice and human rights (Bassu 2008; Carothers 2009; Dworkin 1985; Peerenboom 2002). On the other hand, 'thin' or 'formal' definitions are limited in scope to the form and equal application of the law, how the law is produced, and the role it should play in society (Krygier 2011, 2015; Trebilcock and Daniels 2008). Thin definitions consider the rule of law as being in place when a comparatively limited set of rules and laws are implemented effectively (Raz 1979; Trebilock \& Daniels 2008).

International organisations and non-governmental organizations often adhere to 'thick' definitions of law, whereas governments, especially those of authoritarian and non-liberal states, tend to prefer a 'thin' and narrow definition. Notably, thin definitions are also favoured by some modern analytical jurists, legal philosophers and legal corporativists yet other scholars often find them problematic because thin definitions may be used to justify or legitimise severe human rights violations (Dworkin 1985; Selznick 1992). Critics note for example that in the past, thin conceptualisations have allowed victims to be sent to gas chambers under the justification that this was legally permitted (Bingham 2010). The idea that conformity and a system of government that pays 'due respect' to the rule of law is better than one that does not is therefore argued to be intrinsically problematic in such cases, thereby refuting the idea that conformity to law is necessarily morally right (Zanghellini 2016: 219). By extension, questions of justice are often overlooked when the rule of law is flouted in draconian regimes. These regimes are likely to focus on 'thin' definitions, thus neglecting issues concerning how power should be exercised, resources distributed and used, and how disputes or conflicts should be resolved (Domingo 2016).

Some scholars describe thin interpretations of the rule of law as a 'rule by law' (Moller \& Skaaning 2012), noting again that they lack a substantive concern with just outcomes and the protection of 
human rights (Selous 2016; see Belton 2005; Mooney 2014 for expansive interpretations). Discussion of the 'rule of law', as opposed to a 'rule by law' bridges Northern and Southern understandings and conceptualisations, with the latter normatively taken to indicate an authoritarian style of 'rule of law' in Southern, non-liberal, less (or limited) democratic regimes. In these contexts, legal institutions do not act as an effective constraint on state power or a source of accountability (Peerenboom 2004), but rather a basis for legitimising the use of political power by a regime (Krygier 2011). In countries where effective legitimation requires the ruling regime to maintain an outwardly liberal appearance, rule by law may occur subtly or covertly (see Rajah 2012: 17 on Singapore). By contrast, rule by law may appear more overt in countries that have historically eschewed Western liberal political values (Blasek 2014).

A related concept is that of a 'culture of lawfulness'. This denotes the idea that 'the dominant or mainstream culture, ethos, and thought in a society are sympathetic to the rule of law' (Godson 2000: 92). Within such a culture, 'the average person believes that legal norms are either a fundamental part of justice or provide the gateway to attain justice and that such a system enhances the quality of life of individuals and society as a whole' (Godson 2000: 93). Underpinning this idea is an argument that regulatory approaches and strong institutions alone are insufficient for creating or maintaining lawful and orderly societies (Godson 2000: 92). Accordingly, Godson suggests that civic and school based education, centres of moral authority, and positive media messaging which reinforces 'the values that make for law-abiding, values-oriented citizenship' (p. 97) are the core ingredients for building a culture of lawfulness in any society.

The concept of a 'culture of lawfulness' is noteworthy in the SDG context because it sits at the heart of the Doha Declaration adopted at the Thirteenth UN Congress on Crime Prevention and Criminal Justice. The Doha Declaration recognises the link between rule of law and sustainable development and commits Member States 'to the promotion of a culture of lawfulness that supports the rule of law and human rights while respecting cultural identities' (United Nations Office on Drugs and Crime, 2015: 12). The statement's dual emphasis on supporting human rights and respecting cultural identities reflects the political and ideological tensions that gave rise to the definitional debates surrounding the rule of law. Specifically, the emphasis on human rights is consistent with the UN's liberal mandate, which as previously noted reflects a thick definition of the rule of law based universal principles. By contrast, the inclusion of 'respecting cultural identities' should be read as a caveat acknowledging the fact that these values are not shared or celebrated by all Member States. From a political standpoint, this compromise is important because it creates space for Member States to selectively engage with the agenda and disregard those elements that they perceive to be antithetical to their cultural values. Adopting what might be described as a flexible approach to promoting the rule of law is therefore necessary for establishing and maintaining broad international support for the idea and its off-shoot, a 'culture of lawfulness'. 
Finally, it is worth noting that the idea of a 'culture of lawfulness' sits at the heart of the 'Education for Justice' (E4J) initiative that is administered by UNODC and funded by the State of Qatar. As described on Global Programme's website, the E4J initiative 'seeks to prevent crime and promote a culture of lawfulness through education activities designed for primary, secondary and tertiary levels' (UNODC 2019a). The curriculum itself covers a wide array of issues including core 'values such as acceptance, integrity, respect and fairness' at the primary level and specific types of criminal activity such as corruption and trafficking at the secondary and tertiary levels (UNODC 2019b). The curriculum was developed with input from educators and civil society actors and has been designed so that teachers can selectively adopt resources that are relevant to their teaching needs and which are culturally appropriate. Once again, this initiative illustrates the international community's on-going commitment to advancing a flexible definition of the rule of law.

\section{Measuring SDG 16.3}

The lack of definitional consensus described in the previous section renders the prospect of measuring national and international progress towards SDG 16.3 inherently problematic. The two official indicators that have been developed for this target are:

16.3.1: Proportion of victims of violence in the previous 12 months who reported their victimization to competent authorities or other officially recognized conflict resolution mechanisms.

\subsection{2: Unsentenced detainees as proportion of overall prison population.}

The UN has published a metadata document for each SDG target developed by UNODC and the Office of the United Nations High Commissioner on Human Rights (OHCHR) which details the following for each target indicator: definition and method of computation; rationale and interpretation; sources and data collection; disaggregation; comments and limitations; gender equality issues; data for global and regional monitoring; and supplementary information and references (UN, 2016). For indicator 16.3.1, "competent authorities" can include police, prosecutors, or others with the authority and competency to investigate certain crimes such as corruption or fraud (UN, 2016). Additionally, informal justice or dispute resolution agents such as tribal or religious leaders, village elders, and community leaders can participate if state authorities officially recognize them. The rationale for the first indicator (16.3.1) is that lack of trust and confidence in authorities can reduce reporting rates; rates of reporting crimes can be considered a direct measure of confidence in the police and authorities as well as a measure of the 'dark figure' of crime. This of course assumes that one has good victimization survey data, as victimization surveys provide direct information on reporting rates to authorities. As the UN (2016) acknowledges, however, only 72 countries have implemented at least one survey since 2009.

UNODC is tasked with overseeing the collection of this data due to their on-going responsibility for collecting data on crime reporting rates annually as mandated by the UN General Assembly (UN, 2016). 
It should be noted, however, that as of 2016, crime-reporting data from UNODC were only available for 35 countries (UN, 2016). UN (2016) recommended disaggregation of the data to include sex, type of crime, ethnicity, migration background, and citizenship. The UN (2016) further notes that indicator 16.3.1 does not cover civil or administrative disputes, but recommend that feasibility studies are undertaken to see if the measure could be included. The document also notes the difficulty of comparing gender disparities in reporting crimes to authorities, as women in particular might be reluctant to report domestic violence for reasons other than lack of trust in the police, such as fear of retaliation from their abusers.

Metadata information for indicator 16.3.2 comes from UNODC and the Technical Support Team Working Group (UN, 2016). As is written in the document:

'Sentenced' refers to persons subject to criminal proceedings who have received a decision from a competent authority regarding their conviction or acquittal. For the purposes of the indicator, persons who have received a 'non-final' decision (such as where a conviction is subject to appeal) are considered to be 'sentenced'. (UN, 2016: 16).

The rationale for this indicator is that persons awaiting trial should not be detained in custody when it is not necessary, and are presumed to be innocent until proven guilty. Pre-trial detention places financial burdens on criminal justice systems and on families of those detained (UN, 2016). Data for the indicator would come from UNODC, which collects data annually on unsentenced and total detainees for 114 countries, and from research institutions and NGOs, which are estimated to provide data for an additional 70 countries. It is also recommended that data are disaggregated based on age, sex, and length of pre-trial detention. Data for global monitoring could come from the UN Survey of Crime Trends and Operations of Criminal Justice Systems. Regional data could come from the Council of Europe Annual Penal Statistics and the Organization of American States Observatory on Citizen Security Data Repository.

The meeting of this target is premised on assumptions about accessible and functional criminal justice systems, staffed by competent, conscientious and uncorrupted individuals in a context where accessibility is matched by the ability of/and willingness to access services and most importantly, the ability to do so without fear of repercussions of such undertakings. Such functionality of the justice system would also suggest defendants are able to promptly face their accusers as opposed to being detained for extended periods without convictions.

It is laudable that SDG 16.3 seemingly adheres to a thick definition of the rule of law and access to justice. However, the adequacy of target indicators has been questioned. As Satterthwaite and Dhital (2019) demonstrate, SDG 16.3 emphasizes a narrow set of criminal justice system indicators at the expense of civil justice metrics that cover concerns ranging from land disputes, evictions, labor 
grievances, divorce, and the like. Part of the reasoning for this was the desire to have measures for access to justice that were official, measurable, and readily available. UNODC in particular successfully pushed to narrow the focus of 16.3 .1 from 'those who experienced a dispute...who have accessed a fair formal, informal, alternative, or traditional dispute mechanism' to 'victims of violence' who 'reported to competent authorities or other officially recognized conflict resolution mechanisms,' contending that since UNODC was already tracking these measures they could start analyzing data immediately (Satterthwaite and Dhital, 2019: 98-99). This also allowed UNODC to maintain custodianship over SDG 16.3, but organizations such as the Technical Support Team and the Virtual Network (which included organizations such as UNDP and the World Bank) preferred the previous broader statement they helped develop that also focused on dispute mechanisms beyond formal criminal justice systems, stating that they had developed the methodologies and technical capacities to collect data necessary for measuring the broader approach, and that UN member states, including developing countries, were committed to building technical capacities to participate (Satterthwaite and Dhital ,2019). Satterthwaite and Dhital (2019) also discussed the role of civil society groups, who agreed that a broader framework was needed, and suggested indicators on issues such as confidence in criminal justice systems and whether or not public defenders are provided to indigent defendants. As one can see from the final product, however, UNODC, with its established and anchored expertise in criminal justice issues, were successful in promoting their approach. Satterthwiate and Dhital (2019) argue that this very political process that included a resistance to new methodologies and sources of data was veiled by a focus on technical issues such as official data and appeals to readily available broad coverage.

Reliance on official measures, however, cannot be guaranteed to produce valid and reliable data, as international crime and court data are notoriously faulty in numerous ways, including coverage and accuracy (Neopolitan 1997). As mentioned above, by 2016 only 72 countries have implemented at least one victimization survey since 2009, and crime-reporting data from UNODC are only available for 35 countries. In addition, we contend that the recommended disaggregation of the data is not sufficient to assess the target. For 16.3.1, recommended disaggregation of the data include sex, type of crime, ethnicity, migration background and citizenship, but this leaves out critical variables such as age, region/urban/rural residency, and LGBTQIA status. For 16.3.2, recommended disaggregation focuses on age, sex, and length of pre-trial detention, but this leaves out ethnicity, age, citizenship/migration status, region/urban/rural residency, and LGBTQIA status.

Another major issue concerns who counts as "competent authorities" to receive reports of crime or engage in conflict resolution. As stated in the metadata document, community leaders can participate if they are officially recognized by state authorities. Members of numerous indigenous or other marginalized groups, including women, may not be officially recognized as competent by state authorities. Groups and individuals officially being recognized as part of civil society, or as part of "the 
local," is often a contested process (Hirblinger \& Simons, 2015; Howell \& Pierce, 2001). Even if they are recognized as part of the local, civil society groups or local leaders may lack capacity, or be perceived to lack it by the local government or foreign donors, leaving out key constituencies that can provide meaningful information on crimes in a particular area.

Finally, it is important to note that alternative perception-based measures do exist in the form of indices such as the World Justice Project's Rule of Law Index. These rankings are derived from a General Population Poll ( $\mathrm{n}=1000)$ and a Qualified Respondents' Questionnaire, which are administered annually to allow for benchmarking. Unlike the SDG 16.3 indicators, the Rule of Law Index captures a broad definition of the rule of law that focuses on eight factors: constraints on government powers, absence of corruption, open government, fundamental rights, order and security, regulatory enforcement, civil justice, and criminal justice (World Justice Project 2019). Each of these factors includes a number of sub-factors, some of which reflect a thick definition of the rule of law and others a thin definition. The WJP justifies this definitional approach by stating that " $[\mathrm{s}]$ triking this balance between "thin" and "thick' conceptions of the rule of law enable the Index to apply to different types of social and political systems, including those that lack many of the features that characterize democratic nations, while including sufficient substantive characteristics to render the rule of law as more than a system of rules' (World Justice Project 2019: 8). Again this illustrates the fact that universalising this ideal necessitates a flexible definition.

The inclusion of 'thick' criteria in the Rule of Law Index is laudable and unlike victim surveys, this survey-based methodology which focuses on perceptions lends itself to global coverage. Unfortunately, the scores generated from the survey responses are subjective, reductionist, provide no real insight into how the various criteria interact with each other in specific contexts, and are likely skewed by the same perception bias affecting the much-criticised Corruption Perceptions Index which is published annually by Transparency International (see Andersson and Heywood 2009). A further consideration is that the reliability of the measures (i.e. sub-factors) and their impact on the overall score is unclear, especially when one considers that three economically prosperous Asian countries/jurisdictions with weak human rights records and limited political freedoms (i.e. Singapore, Hong Kong SAR and Republic of Korea) rank in the top twenty. As discussed later in this chapter, this raises questions about the empirical value of benchmarking countries based on their adherence to an ill-defined and contested. At best this suggests that benchmarking should be understood as a political exercise designed to incentivise conformity by national governments to global economic and political norms. That is to say, the existence of perceptions based measures, regardless of their methodological limitations, generates strong reputational incentives for governments and political elites to adopt policy measures that at least pay lip service to the rule of law. Whether these measures translate into actual practices is of course another question. 


\section{Rule of law in Western democracies}

With few exceptions (for example, Qatar's financial support for the E4J initiative), international efforts to promote the rule of law have historically been championed and financed by Western governments, which are seen as model democracies. In the aftermath of the Cold War, the idea that transnational organised crime and corruption represented emergent threats to the rule of law have provided added impetus to advance this agenda, particularly when it is advanced in countries labelled 'weak', 'fragile', 'transitional', or 'failed' (Shelley 1995). Rule of law programming has thus emerged as an important component of international aid and state building programmes throughout the Global South (Fukuyama 2004). Underpinning these activities is an enduring assumption that political liberalisation goes hand-in-hand with economic development. That is, well-established and functional democracies are seen to represent the building blocks of a global political economy that is grounded in neoliberal ideas. The illusion here is that within a well-established and functional democracy: appropriate and adequate laws protect human rights of all individuals despite status, class or position of power; individuals are held accountable for their actions; there is fairness and uniformity in the application of laws; and all citizens have a relatively sound understanding of laws or at least an awareness of the institutions that are involved in rule of law preservation. In such a system, government officials are unbiased, uncorrupted and serve the interest of the population; members of the judicial institution are well trained and operate within functional systems; and local stakeholders (citizens) participate in the conception of law and justice. Such assumptions about liberal democracies are based on ideals promoted by Western powers who interestingly fail to live up to this international standard (Carothers 2006).

An example of this is the United States, which continues to proclaim itself a model democracy, and is ranked a respectable 20th on the World Justice Project's Rule of Law Index 2019 (World Justice Project 2019). In a neoliberal era where inequality is increasing, regulatory agencies overseeing financial, business, security, and criminal justice activities run by political appointees are weakened by reduced budgets, and relatively large sums of money are needed to operate successful political campaigns, US institutions are less able to control political corruption or uphold the rule of law. The reality for many citizens of the United States is a lack of access to justice (Matthews \& Botero, 2010; Rhode 2001). In particular, the poor lack access to affordable legal counsel (Matthews \& Botero, 2010), and as Rhode (2001: 1785) states: 'An estimated four-fifths of the civil legal needs of the poor, and the needs of an estimated two- to three fifths of middle-income individuals remain unmet. Governmental legal services and indigent criminal defence budgets are capped at ludicrous levels, which make effective assistance of counsel for most low-income litigants a statistical impossibility'. Furthermore, under both Democratic and Republican administrations, there are numerous complaints about the failure of laws to protect all US citizens as immigrants and asylum seekers face high levels of deportation, detention and denial of an opportunity to a fair hearing; and police violence against African-American, 
indigenous, and other marginalized groups occurs at an alarming rate. Conformity to a thick definition of the rule of law has also been sidestepped in the US War on Terror as post-9/11 legislation, including the Patriot Act, has made abuses of power and human rights violations more likely. The drone program expanded during the Obama administration further demonstrates that the US government acts as if it has the legal right to execute any person it determines is a member of a terrorist organization no matter where the person is or whether or not the person is a US citizen, based on secret criteria and evidence and without public discourse or institutional oversight (Friedersdorf 2014). In addition, the Foreign Intelligence Surveillance Court operates without transparency, sanctioning the violation of privacy rights inside and outside of US borders.

Similarly, Australia has long occupied the position of a model democracy for most of the Pacific as well as the position as the Pacific's leading donor. It is ranked $11^{\text {th }}$ on the WJP Rule of Law Index despite multiple discussions about breached human rights at off shore detention centres and the on-going victimisation of Indigenous Australians by the criminal justice system. Furthermore, despite a right under the law to access justice, many non-Indigenous Australians are also denied said access owing to a lack of available resources. For example, research conducted by the Australian Law Reform Commission relating specifically to persons with disabilities identified unavailable finances, difficulties accessing necessary support, communication and prevailing stereotypes as barriers to access justice (Clarke, Forell \& Gray 2009). This reality also extends to many low-income Australians as McLeod (2017) highlighted that more than $13 \%$ of the Australian population lives under the poverty line, yet legal aid is only available for $8 \%$ and the legal assistance sector budget has undergone twenty years of steady cuts. Finally, there is also the need to consider false indicators of success in relation to personal choice. Specifically, Australia's 'stolen generation' of Indigenous persons provides a historical context for distrust in legal processes and partially explains persons opting not to use their right to access justice for fear of repercussion (Altman \& Hinkson 2007). We make this point not to stray from the issue of access to justice but to show that questionable or damaging models of rule of law may foreground the issue of a lack of access to justice.

By highlighting some rule of law deficiencies inherent to model democracies, our intention is not to discredit the concept altogether or adopt a purely relativistic stance. Rather, we feel that highlighting these deficits is useful for emphasizing the fact that " $[\mathrm{n}]$ o society has ever attained - let alone sustained - a perfect realization of the rule of law' (World Justice Project 2019: 8). The fact that international efforts to promote the rule of law continue to focus on developing countries from the Global South rather than developed countries in the Global North is thus a reflection of how power is distributed throughout the global political economy. Countries like the United States and Australia shape international norms and values while weaker countries are expected to adapt and conform. In cases where governments of developing countries are unable or unwilling to adhere to these norms, they may be compelled to do so through various measures. These range from conditions attached to loans or 
debt forgiveness packages to technical assistance and in extreme cases, international interventions. It is important, then, that US and other Western democracies work on their own rule of law deficiencies if they are to have any legitimacy in pressuring countries in the global South to do the same, particularly when many countries in the South are working within governmental and legal systems held over from the time when Western democracies brutally colonized them. In addition, Western countries should provide adequate support for these measures in a way that would benefit countries in the South, rather than propping up authoritarian 'rule by law' regimes and using rule of law initiatives for the benefit of the Western countries providing aid.

\section{Solomon Islands: promoting the rule of law in a 'failed' state}

The Solomon Islands are a representation of the aforementioned paradox of the rule of law agenda: rule of law programming is often hardest to institutionalise where it is thought by liberal reformers to be needed most. By examining these challenges inherent to institutionalizing the rule of law in postcolonial countries, we can better understand the obstacles to realising SDG 16.3. We draw specifically on the example of the Solomon Islands because it is a Pacific Island country known for high levels of population growth, low education levels, high unemployment and significant inequality. With an estimated population of 572,000 , it is also documented to have one of the highest rates of family and sexual violence in the world, with $64 \%$ of women aged $15-49$ having reported physical and/or sexual abuse by a partner (Ming. et., al. 2016). Several arguments exist about the formal establishment of democracy or statehood in Solomon Islands. Unlike many former British Protectorates, colonial presence was not as engaged, which meant statehood was not as well established as it was in other neighbouring former colonies or protectorates (Alpers \& Twyford 2003). Continuing traditional structures were not considered in the establishment of statehood, which contributed to clashes or a poorly functioning intersections between state and traditional structures devoted to maintaining law and order (Alpers \& Twyford 2003, Wainwright 2003).

Following the ethnic conflict, which erupted in 1998 between the Guadalcanal and Malaita, much international intervention was sought to restore governance. The collapse of the democratic system not only resulted in international intervention to restore governance, but also large-scale aid by the Australian-led regional force (RAMSI), who provided the necessary assistance to restore law and order. The Australian and New Zealand governments committed to providing assistance in order to restore the machinery of government, and improve accountability, law and justice. Despite well documented progress to restore democracy, the process of (re)building public trust continues to be affected by allegations of government corruption, wantokism, and uneven distribution of resources. There also continues to be areas where individuals do not adhere to or acknowledge state laws. Such areas where lawlessness prevails have been categorized as no-go zones and are documented as being controlled by former militants who continue to possess firearms (Alpers \& Twyford 2003). What is also 
likely to affect crime reporting in Solomon Islands is the existence of the No Drop (Sexual Violence) Policy, which reflects zero tolerance with regards to sexual offences and Domestic Violence. The policy directly clashes with principles of wantokism and local beliefs about the role of the male figures as disciplinarians within a family structure.

The Solomon Island context bares many similarities with other failed democracies across the globe: governments rendered non-functional, breakdown in law and order, limited service delivery and poor access to social goods and services, transference of public allegiances away from central authority towards ethnic groups or clans, humanitarian crisis and sharp decline in standard of living (Wainwright 2003). Independent judiciaries are impacted by strained resources, corrupt officials and lack of public trust in the system. Where governments lack legitimacy in the eyes of the public, reliance on legislative systems, state institutions and state representatives charged with the responsibility of upholding law and order are highly unlikely and unrealistic. The focus in such context is the restoration of law and order and capacity building at the state or institutional levels. The emphasis on rebuilding in itself is an acknowledgement of the under-functionality of the democratic machinery. Promotion of rule of law and access to justice and the meeting of target indicators in such context within the timeframe indicated for attainment of the SDG can be simply described as ambitious.

For titular democracies, poorly functional legal systems compromise the ability to effectively protect the civil and political rights of members of the respective societies, threatening the hopes of promoting thick notions of the rule of law. In many of these contexts, it would be presumptuous to assume that access to justice can be improved by simply addressing shortfalls in the legislative system, which in most instances are built on brutal colonial histories (Watson and Kerrigan 2018), the positioning and protecting of powerful political elites (Alter 2010), or exist parallel to accepted and well respected traditional non-Western systems of justice (Carothers 2006). Adaptations to meet the indicators in such contexts are prone to become a messy cut and paste arrangement of targeted judicial systematic overhauls intended specifically to meet an identified purpose. The choices made in such contexts are likely influenced by one or multiple factors inclusive of but not limited to - abrupt and drastic change initiated by international pressure, the selected or transposed Western model, the primary source of donor funding, political posturing, or the state of democracy at the point of commencement. Apart from the rule of law, contextual variables including but not limited to increased privatization of criminal justice functions, para-militarization, the weakening of legal protections for criminal defendants, patriarchy, bias against various ethnic, sectarian, and sexual minority groups, and hyper focus by many on certain transnational crime and violence issues such as terrorism, human and drug trafficking are likely to impact the meeting of set sustainable development targets. 
Promoting a culture of lawfulness via education-focused initiatives coupled with quick-fix institutional reforms based on 'thin' conceptions of the rule of law are not sufficient to overcome these contextual realities. Unfortunately, however, in contexts such as Solomon Islands, indicators focused on the functioning or access to judicial systems are likely to prioritize institutional capacity building as opposed to developing strategies that connect all members of society with the law. Carothers (2006: 2021) argues:

Clearly law is not just the sum of courts, legislatures, police, prosecutors, and other formal institutions with some direct connection to law. Law is also a normative system that resides in the minds of the citizens of a society. As rule-of-law providers seek to affect the rule of law in a country, it is not clear if they should focus on institution building or instead try to intervene in ways that would affect how citizens understand, use, and value law. To take a simple example, many rule-of-law programs focus on improving a country's courts and police on the assumption that this is the most direct route to improve compliance with law in the country. Yet some research shows that compliance with law depends most heavily on the perceived fairness and legitimacy of the laws, characteristics that are not established primarily by the courts but by other means, such as the political process.

As with the Solomon Islands, many countries struggle with inadequately performing governance structures unable to meet the needs of its citizenry adequately. In such contexts, citizens can be justly expected to have little respect or confidence in government institutions and justice systems.

Attempting to 'fix' the system without aligning it to what Carothers describes as "genuinely democratic values and practices" works in the disservice of meeting target indicators. Even if we apply a democratic lens to restrict our discussion of SDG 16.3 target indicators, in doing so we acknowledge the complexity of rule of law and access to justice in transitional states, post-communist states and postconflict societies. We also acknowledge the complexity of democracy and its potential to be ceremonial as opposed to active and functional, while also recognizing that many transitionary and titular democracies are characterized by their violations of human rights within a 'rule by law' approach to governance.

We should emphasize here that the issue is not just a lack of institutional capabilities and/or the failure to promote a culture of lawfulness or link reform to democratic norms. Perhaps more important is the questionable resonance or compatibility of Western liberal norms with local cultural and political norms and circumstances. This is clearly an obstacle for realising SDG 16.3, which is already narrowly defined with these liberal norms and designed to be monitored using insufficient measures as we noted above. This issue of compatibility cannot be fixed with increased international aid budgets, or as we have seen in numerous recent cases, military interventions. 


\section{Singapore: order and security at a cost}

In Singapore, the importance of the 'rule of law' is openly extolled by the government subscribes to a thin definition of the concept. The country ranks 13th overall in the 2019 Rule of Law Index which reflects its 1st place ranking in the 'Order \& Security' category and 3rd place rankings for both 'Absence of Corruption' and 'Regulatory Enforcement'. By comparison, Singapore's rankings for the categories of 'Fundamental Rights' (30th) and 'Open Government' (25th) illustrate that adhering to a limited, thin definition of the rule of law may be sufficient for creating an orderly, investor friendly environment. Accordingly, the example highlights the importance of looking beyond western and international liberal democratic assumptions concerning the rule of law in advanced liberal democracies. At the same time, it highlights how government efforts to promote order and security have historically contributed to deficiencies in access to justice, human rights abuses, and restrictions on civil and political liberties.

As a starting point, it is important to note that Singapore has long been criticised for its approach to the rule of law. Critiques emphasise that the government has systematically "dismantled" British notions of the 'rule of law' into one that evinces a quality of "legal terrorism" (Asia Watch 1989, Tremewan 1994, Seow 1997 in Thio 2002: 6). Singapore has been described as a "dichotomous" "regime that has systemically undercut 'rule of law' freedoms while managing to be acclaimed as a 'rule of law' state" (paraphrased from Thio 2002: 7; Rajah 2012: 3). The international community has seemingly turned a blind eye to these critiques because the government has used its power to establish Singapore as an economically stable and prosperous nation. This successful transition represents an important element of the national identity and the country's economic prosperity, stability, and international reputation as a 'First World', investor friendly nation remains an important source of political legitimacy for the government, both domestically and internationally. The story of Singapore's success has also attracted many "powerful admirers" (Rajah 2012: 6), including China and Vietnam, which have attempted to replicate its approach to the rule of law in the process of managing their own transitions and integration into the global economy (see Rodan 1998; Ortmann \& Thompson 2018). Their attraction to the Singaporean model is based on the fact that its state-modified 'rule of (by) law' system that does not follow liberal or democratic notions of "uncontrolled, independent judicial power, or significant political opposition" with "limits" and "strict separation of powers" (Silverstein 2008: 74, 76). As such, Singapore "demonstrates how economic development and liberalisation can take place apart from political liberalisation" (Thio 2012:272).

Singapore models its legal system on the 'shell of the Westminster' system (Rodan 2005; Rajah 2014: 140). The rule of law is not formally enshrined in Singapore's Constitution, but reinforced and lauded through practice and political discourse (Thio 2002). 'Inherited' British law was modified to allow for economic development and meet "the political, social and cultural values" of Singapore (Chan 2009 in 
Rajah 2017: 370). Liberal ideas and political pluralism existed briefly in Singapore during the PostWorld War II period (Harper 2001; Hong \& Huang 2008; Barr \& Trocki 2008) however this was soon after replaced by a strict rule by law ethos that continues to be practiced in the state (Rajah 2012; Thio 2012). This illiberal approach was not uncommon for Third World regimes the decades of decolonization but the longevity of this particular one-party regime which has been in power since 1959 is noteworthy (Woodier 2006; Rodan 2005). Historically, this longevity is attributable to state control of media and the government's ability to legitimise its illiberal actions to citizens by emphasising the validity of Singapore 'law' (see Thio 2002: 6; Rajah2012: 114). In this context, the 'rule of law' is actually invoked by the government to justify the curtailment of what many would view as fundamental rights and freedoms including labour rights, the right to peaceful demonstration, freedom of local press (Peerenboom 2004; Silverstein 2008; Thio 2002). The government also appeals to its legal authority in justifying illiberal criminal justice practices such as pre-emptive detention, detention without trial, the abolition of jury trials, corporal punishment and the death penalty (Rajah 2012; Peerenboom 2004; Thio 2002, 2012).

Problematically, detention without trial, corporal, and capital punishment remain as public and symbolic acts of violence enacted on "bodies" to "secure the nation" (Rajah 2012: 115, paraphrased). This "strong" and "tough" stand is also taken to ensure "a low crime rate" (Jayakumar 2007; see also Yap \& Tan 2020 for Singapore's 'tough stand' in the case of death penalty). This pattern is uniform with other post-colonial states, where sanguinary punishment is regarded as a justifiable response to violent crime (Brown 2003; An \& Yang 2003; Fisch 1983). State officials reiterate that acts of 'force' and 'violence' are 'deservingly' inflicted on “primitive, barbaric peoples” (Said 1994: xi; Rajah 2014: 148; Shanmugam 2014). Following legal and political patterns of Asian counterparts, Singapore asserts 'Asian values' as cultural distinctiveness to evade criticism and accountability for human rights infringements, and prioritise 'British models' that allow commercial transactions (Thio 2002). In this regard, the state claims that it has no choice but to adopt tough and illiberal policies to safeguard order and security as the cornerstone of the 'rule of law' (Shanmugam 2012c). This illustrates both the potential utility and the dangers of normalising thin conceptualisations of rule of law which enhance state power in the interest of promoting economic growth and stability (Peerenboom 2004; Thio 2012). In non-Western contexts, this model may prove conducive to facilitating '[sustainable] development that meets the needs of the present without compromising the ability of future generations to meet their own needs' however it is likely incompatible with a rule of law agenda that seeks to advance social justice and human rights. A flexible approach to rule of law promotion may therefore be useful for sidestepping these inter-cultural tensions but offers little in the way of resolving them. 


\section{Conclusion}

The rule of law has been part of human rights, democracy, and development discourse for a number of decades now, and SDG 16.3 is an acknowledgement of the prevailing norm that the rule of law and access to justice are necessary for achieving human rights for all of the world's peoples. That being said, there is a lack of consensus on how the rule of law should be promoted or supported, particularly in developing and transitional countries in the Global South. An industry has been developed around current neoliberal proponents in the international community linking economic liberalisation with democratic norms regarding the protection of civil and political rights, but this version is not universally accepted. The favourable rankings of Northern democracies in the World Justice Project's Rule of Law Index mask numerous rule of law deficits that make the hegemony of Northern neoliberal conceptions of the rule of law problematic. While Northern actors and their international organizations heavily influence and dominate rule of law discourse and programming, it is apparent that the rule of law and access to justice are inevitably lacking in the wealthiest, most developed countries of the North, disproportionally impacting the poorest, most marginalized groups in those countries such as racial, ethnic, and sectarian minority communities; immigrants; asylum seekers, and indigenous groups. Countries of the global South are also lacking in access to justice and the rule of law, in part because of the legacy of colonialism. Against this historical backdrop, it is important to recognise that the governing institutions of many developing countries were never designed to ensure access to justice and human rights for colonized peoples.

The above concerns demonstrate the challenges facing those seeking to improve the rule of law within the context of the SDGs. To make matters worse, SDG target indicators, despite being well rationalized and informed by adequate measures which draw from a relatively small body of knowledge, appear premised on assumptions about accessible and functional criminal justice systems, manned by competent, conscientious and uncorrupted individuals in a context where accessibility is matched by ability of and willingness to access services and most importantly, the ability to do so without fear of repercussions of such undertakings. Such functionality of the justice system would also suggest defendants are able to promptly face their accusers as opposed to being detained for extended periods without convictions. The reality in most contexts, even model democracies, is the proliferation of corrupt power hoarders with the ability to manipulate rule of law, criminal justice systems which work in the disservice of marginalized groups, established systems of discrimination and a dysfunctional or poorly resourced criminal justice system (Carothers 2006; Przeworski \& Maravall 2003).

In spite of the variety of ways that people around the globe seek access to justice, it is defined narrowly in SDG 16.3, privileging formal criminal justice institutions and the gathering of official data already available to international organizations such as UNODC. Alternative justice systems prevalent 
in some countries in the Global South such as the Solomon Islands, which may or may not conform to prevailing norms of the rule of law, fail to conform to the assumptions of the SDG target indicators. The consequences of this narrow focus include that citizens of countries and NGOs that assist them contending with everyday civil justice issues (divorce, land disputes, labour disputes, etc.) are reduced from agents of change to passive receivers of services (Satterthwaite and Dhital, 2019). Singapore ranks $13^{\text {th }}$ in the Rule of Law Index, even though civil and political liberties are known to be heavily restricted. Apparently a thin definition of rule of law is sufficient for Singapore to rank high on the index: the government's institutions maintain an orderly, investor friendly environment valued by neoliberals. We contend, however, that a 'thick' definition of rule of law that includes civil and political liberties and freedoms in addition to flexibility according to varying cultural and political traditions is necessary for sustainable and truly democratic rule of law promotion. In addition, it is clear that in order to comprehensively assess the rule of law and justice we need an expanded variety of indicators that account for the diverse ways people access justice around the world.

\section{References}

Alpers, P., \& Twyford, C. (2003). Small Arms in the Pacific (p. 169). Small Arms Survey. https://www.files.ethz.ch/isn/87853/2003-03-0P08 Small\%20Arms\%20in\%20the\%20Pacific.pdf

Alter, K. J. (2010). Establishing the Supremacy of European Law: The Making of an International Rule of Law in Europe. Oxford University Press. https://doi.org/10.1093/acprof:0so/9780199260997.001.0001

Altman, J. C., \& Hinkson, M. (2007). Coercive Reconciliation: Stabilise, Normalise, Exit Aboriginal Australia. Arena Publications Association.

Andersson, S., \& Heywood, P. M. (2009). The Politics of Perception: Use and Abuse of Transparency International's Approach to Measuring Corruption. Political Studies, 57(4), 746-767.

https://doi.org/10.1111/j.1467-9248.2008.00758.x

Asia Watch. (1989). Silencing All Critics: Human Rights Violations in Singapore. Human Rights Watch.

Barr, M., \& Trocki, C. (Eds.). (2008). Paths Not Taken: Political Pluralism in Post-war Singapore. NUS Press.

Bassu, G. (2008). Law Overruled: Strengthening the Rule of Law in Postconflict States. Global Governance, 14(1), 21-38. JSTOR.

Belton, R. K. (2005). Competing Definitions of the Rule of Law: Implications for Practitioners. Carnegie Papers, 55, 44.

Bingham, T. (2011). The Rule Of Law. Penguin. 
Blasek, K. (2014). Rule of Law in China: A Comparative Approach. Springer.

Blaustein, J., Chodor, T., \& Pino, N. W. (2020). Making Crime a Sustainable Development Issue: From 'Drugs and Thugs' to 'Peaceful and Inclusive Societies.' The British Journal of Criminology, 60(1), 50-73. https://doi.org/10.1093/bje/azz050

Carfield, M. (2005). Enhancing Poor People's Capabilities through the Rule of Law: Creating an Access to Justice Index Note. Washington University Law Quarterly, 83(1), 339-360.

Carothers, T. (1998). The Rule of Law Revival Essay. Foreign Affairs, 77(2), 95-106.

Carothers, T. (2003). Promoting the Rule of Law Abroad. Carnegie Endowment for International Peace, 34,18 .

Carothers, T. (2006). The Backlash against Democracy Promotion. Foreign Affairs, 85(2), 55-68. JSTOR. https://doi.org/10.2307/20031911

Carothers, T. (2009). Rule of Law Temptations. The Fletcher Forum of World Affairs, 33(1), 49-61.

Domingo, P. (2016). Rule of law, politics and development: The politics of rule of law reform (p. 16). Overseas Development Institute. https://www.odi.org/sites/odi.org.uk/files/resourcedocuments/10420.pdf

Dworkin, R. (1985). A Matter of Principle. Harvard University Press.

Friedersdorf, C. (2014, July 11). America Fails the "Rule of Law" Test-The Atlantic. The Atlantic. https://www.theatlantic.com/politics/archive/2014/07/how-america-fails-the-rule-of-law-test/374274/

Fukuyama, F. (2004). The Imperative of State-Building. Journal of Democracy, 15(2), 17-31. https://doi.org/10.1353/jod.2004.0026

Godson, R. (2000). “Guide to developing a culture of lawfulness,.” Trends in Organized Crime, 5(3), 91102. https://doi.org/10.1007/s12117-000-1038-3

Gray, A., Forell, S., \& Clarke, S. (2009). Law and Justice Foundation-Cognitive impairment, legal need and access to justice (Justice Issues, pp. 1-16). Law and Justice Foundation of New South Wales. http://www.lawfoundation.net.au/report/justiceissues10

Harper, T. (2001). Lim Chin Siong and the “Singapore Story." In J. Q. Tan \& K. S. Jomo (Eds.), Comet in Our Sky: Lim Chin Siong in History. (pp. 3-55). Insan.

Hayek, F. A. (2011). The Constitution of Liberty: The Definitive Edition. University of Chicago Press. 
Hirblinger, A. T., \& Simons, C. (2015). The good, the bad, and the powerful: Representations of the 'local' in peacebuilding. Security Dialogue, 46(5), 422-439. https://doi.org/10.1177/0967010615580055

Hong, L., \& Huang, J. (2008). The Scripting of A National History: Singapore and Its Pasts. Hong Kong University Press.

Howell, J., \& Pearce, J. (2002). Civil Society \& Development: A Critical Exploration. Lynne Rienner Publishers.

Krygier, M. (2011). Four puzzles about the rule of law: Why, what, where? and who care? Nomos, 50, 64104. JSTOR.

Li, L. (2018). The Chinese Road of the Rule of Law. Springer Singapore. https://doi.org/10.1007/978-98110-8965-7

Matthews, R., \& Botero, J. (2010). Access to Justice in the United States: Findings from the Newly Released Rule of Law Index of the World Justice Project. Virigina Lawyer, 59(December), 24-25.

McLeod, F. (2017, August 3). 160,000 people turned away: How the justice system is failing vulnerable Australians. $A B C$ News.https://www.abc.net.au/news/2017-08-03/how-the-justice-system-is-faillingvulnerable-australians/8770292

Ming, M. A., Stewart, M. G., Tiller, R. E., Rice, R. G., Crowley, L. E., \& Williams, N. J. (2016). Domestic violence in the Solomon Islands. Journal of Family Medicine and Primary Care, 5(1), 16-19. https://doi.org/10.4103/2249-4863.184617

Møller, J., \& Skaaning, S.-E. (2012). Systematizing Thin and Thick Conceptions of the Rule of Law. Justice System Journal, 33(2), 136-153. https://doi.org/10.1080/0098261X.2012.10768008

Mooney, L. (Ed.). (2014). Promoting the Rule of Law: A Practitioner's Guide to Key Issues and Developments. American Bar Association.

Neapolitan, J. (1997). Cross-National Crime: A Research Review and Sourcebook. Greenwood.

O'Connor, V. (2015). Defining the Rule of Law and Related Concepts. SSRN Electronic Journal. https://doi.org/10.2139/ssrn.2665650

Ortmann, S., \& Thompson, M. R. (2018). Introduction: The "Singapore model” and China's NeoAuthoritarian Dream. The China Quarterly, 236, 930-945. https://doi.org/10.1017/S0305741018000474

Peerenboom, R. (2002). China's Long March Toward Rule of Law. Cambridge University Press. 
Peerenboom, R. P. (2004). Asian Discourses of Rule of Law: Theories and Implementation of Rule of Law in Twelve Asian Countries, France and the U.S. Psychology Press.

Przeworski, A., \& Maravall, J. M. (2003). Democracy and the Rule of Law. Cambridge University Press.

Rajah, J. (2012). Authoritarian Rule of Law: Legislation, Discourse and Legitimacy in Singapore. Cambridge University Press.

Rajah, J. (2014). Flogging Gum: Cultural Imaginaries and Postcoloniality in Singapore's Rule of Law. Law Text Culture, 18(1), 135-165.

Raz, J. (1979). The Rule of Law and its Virtue. In J. Raz (Ed.), The Authority of Law: Essays on Law and Morality (pp. 211-229). Clarendon Press.

Rhode, D. (2001). Access to Justice. Fordham Law Review, 69(5), 1785-1820.

Rodan, G. (2005). Westminster in Singapore: Now you see it, now you don't. In H. Patapan, J. Wanna, \& P. Weller (Eds.), Westminster legacies: Democracy and responsible government in Asia and the Pacific (pp. 109-128). University of New South Wales Press.

https://researchrepository.murdoch.edu.au/id/eprint/1339/

Rodan, Garry. (1998). The Internet and Political Control in Singapore. Political Science Quarterly, 113(1), 63-89. https://doi.org/10.2307/2657651

Rodriguez, D. B., McCubbins, M. D., \& Weingast, B. R. (2010). The Rule of Law Unplugged. Emory Law Journal, 59, 1455-1494.

Said, E. W. (1994). Culture and Imperialism. Random House.

Satterthwaite, M. L., \& Dhital, S. (2019). Measuring Access to Justice: Transformation and Technicality in SDG 16.3. Global Policy, 10(S1), 96-109. https://doi.org/10.1111/1758-5899.12597

Sellers, M. N. S. (2014). What is the Rule of Law and Why is It so Important? In J. Silkenat, J. Hickey, \& P. Barenboim (Eds.), The Legal Doctrines of the Rule of Law and the Legal State (pp. 3-13). Springer. https://papers.ssrn.com/abstract=2445057

Selous, E. (2016). The Rule of Law and the Debate on it in the United Nations. In C. A. Feinäugle (Ed.), The Rule of Law and Its Application to the United Nations (1st ed., pp. 13-28). Nomos Verlagsgesellschaft $\mathrm{mbH} \&$ Co. KG. https://doi.org/10.5771/9783845275017-13

Selznick, P. (1994). The Moral Commonwealth: Social Theory and the Promise of Community. University of California Press. 
Seow, F. (n.d.). The Politics of Judicial Institutions in Singapore.

https://jesscscott.files.wordpress.com/2015/05/politics francisseow1997.pdf

Shanmugam, K. (2012). The Rule of Law in Singapore. Singapore Journal of Legal Studies, 357-365.

https://doi.org/10.2139/ssrn.2255270

Shelley, L. I. (1995). Transnational Organized Crime: An Imminent Threat to the Nation-State? Journal of International Affairs, 48(2), 463-489.

Silverstein, G. (2008). Singapore: The Exception That Proves Rules Matter. In T. Ginsburg \& T. Moustafa (Eds.), Rule by Law: The Politics of Courts in Authoritarian Regimes (pp. 73-101). Oxford University Press.

Tamanaha, B. Z. (2004). On The Rule of Law: History, Politics, Theory. Cambridge University Press.

Tamanaha, B. Z. (2012). The History and Elements of the Rule of Law. Singapore Journal of Legal Studies, 232-247.

Thio, L. (2002). 'Lex Rex or Rex Lex: Competing Conceptions of the Rule of Law in Singapore.' UCLA Pacific Basin Law Journal, 20(1), 1-76.

Thio, L. (2012). Between Apology and Apogee, Autochthony: The 'Rule of Law' Beyond the Rules of Law in Singapore. Singapore Journal of Legal Studies, 269-297.

Transforming Our World: The 2030 Agenda for Sustainable Development, Pub. L. No. A/RES/70/1 (2015). https://doi.org/10.1891/9780826190123.ap02

Treblicock, M. J., \& Daniels, R. J. (2008). Rule Of Law Reform And Development: Charting the Fragile Path of Progress. Edward Elgar Pub.

Tremewan, C. (2016). The Political Economy of Social Control in Singapore. Springer.

United Nations. (2016). Goal 16 Promote peaceful and inclusive societies for sustainable development, provide access to justice for all and build effective, accountable and inclusive institutions at all levels. https://unstats.un.org/sdgs/files/metadata-compilation/Metadata-Goal-16.pdf

United Nations Development Programme. (2017). Rule of Law Annual Report 2017. UNDP. https://www.undp.org/content/undp/en/home/librarypage/democraticgovernance/access to justiceandruleoflaw/rule-of-law-annual-report-2017.html

Declaration of the High-level Meeting of the General Assembly on the Rule of Law at the National and International Levels, Pub. L. No. A/RES/67/1 (2012). https://www.un.org/ruleoflaw/files/A-RES-67- 
1.pdf

United Nations Office on Drugs and Crime. (n.d.). Doha Declaration Global Programme. Retrieved January 13, 2020, from https://www.unodc.org/dohadeclaration/en/index.html

Doha Declaration on Integrating Crime Prevention and Criminal Justice into the Wider United Nations Agenda to Address Social and Economic Challenges and to Promote the Rule of Law at the National and International Levels, and Public Participation, 22 (2015).

https://www.unodc.org/documents/congress/Declaration/V1504151 English.pdf

United Nations Office on Drugs and Crime. (2019). E4J Tools and Materials.

https://www.unodc.org/e4j/en/primary/e4j-tools-and-materials/index.html

The rule of law and transitional justice in conflict and post-conflict societiesz: Report of the Secretary General, S/2004/616 (2004). https://www.securitycouncilreport.org/atf/cf/\%7B65BFCF9B-6D27-4E9C8CD3-CF6E4FF96FF\%7D/PCS\%20S\%202004\%20616.pdf

Wainwright, E. (2003). Our Failing Neighbour: Australia and the future of Solomon Islands. Australian Strategic Policy Institute. https://www.aspi.org.au/report/our-failing-neighbour-australia-andfuture-solomon-islands

Waldron, J. (2002). One Law for All-The Logic of Cultural Accommodation John Randolph Tucker Lecture. Washington and Lee Law Review, 59(1), 3-36.

Watson, D., \& Kerrigan, D. (2018). Crime, Criminality, and North-to-South Criminological Complexities: Theoretical Implications for Policing 'Hotspot' Communities in 'Underdeveloped' Countries. In K. Carrington, R. Hogg, J. Scott, \& M. Sozzo (Eds.), The Palgrave Handbook of Criminology and the Global South (pp. 611-632). Springer International Publishing. https://doi.org/10.1007/978-3-319-65021-0 30

Woodier, J. (2006). Securing Singapore/Managing Perceptions: From Shooting the Messenger to Dodging the Question. The Copenhagen Journal of Asian Studies, 23(1), 57-80.

https://doi.org/10.22439/cjas.v23i1.692

World Justice Project. (2009). The World Justice Project Rule of Law Index 2019 (pp. 129-130). World Justice Project. http://ascelibrary.org/doi/10.1061/\%28ASCE\%2915326748\%282009\%299\%3A3\%28129\%29

Zanghellini, A. (2016). The Foundations of the Rule of Law. Yale Journal of Law \& Humanities, 28(2), 213240. 


\section{Footnotes}

1. Insofar as the 'rule of law revival' (Carothers, 1998) coincided with the collapse of the Soviet Union and the rise of global (neoliberal) capitalism, we feel it is perhaps useful to reflect on the importance attached to the 'rule of law' by the economist Friedrich Hayek, a founder of the neoliberal movement. In Hayek's words, rule of law 'means that government in all its actions is bound by rules fixed and announced beforehand-rules which make it possible to foresee with fair certainty how the authority will use its coercive powers in given circumstances and to plan one's individual affairs on the basis of that knowledge' (Hayek, 1960: 72 as quoted by Carfield, 2005: 347). As Carfield explains, Hayek's emphasis was that the rule of law represents a precondition for economic development insofar as it denotes the presence of orderly conditions that were thought to be necessary for his free market ideology to thrive. The point to emphasise is that the neoliberal embrace of this concept was not initially grounded in deontological concerns about the intrinsic importance of the rule of law but rather, an ideological agenda and material considerations. 